\title{
Scanning Electron Microscopy of Brain Sand in the Bovine Pineal Gland
}

\author{
Norimitsu Kawamura, Takehiko Ishibashi \\ and Hajime Miyamoto \\ Department of Animal Science, Faculty of Agriculture, \\ Ky oto University, Kyoto-shi 606
}

(Received May 16, 1986)

Key words : SEM, pineal gland, brain sand, cattle

Brain sand (Acevulus cerebri) is known to appear in the bovine pineal gland, though its functional significance still remains obscure ${ }^{1)}$. In the previous study ${ }^{2)}$, we detected, by electron probe X-ray microanalysis, large amounts of calcium and phosphorus, and small or trace amounts of magnesium, strontium and sulphur in bovine pineal sand. In the present paper, we will describe the localization and appearance of bovine pineal sand examined with a scanning electron microscope (SEM).

\section{Materials and Methods}

Fourteen pineal glands obtained from adult cattle slaughtered at a local abattoir were used in this study. The pineal glands were cross-sectioned at $2 \mathrm{~mm}$ in thickness and fixed by submersion in $2.5 \%$ glutaraldehyde. After rinsing them in a phosphate buffer, the tissues were dehydrated in a graded series of alcohols, immersed in isoamylacetate and dried via the critical point method using carbon dioxide. The dried tissues were mounted on SEM specimen stubs, coated with gold and observed under a scanning electron microscope (Hitachi S-405).

\section{Results and Discussion}

Of the 14 pineal glands, 6 were recognized to contain brain sand at the SEM level. In all 6 pineal glands the concretions of brain sand were predominantly localized in the central areas of the glands (Figs. A and B). They were made up of a large number of spherulites ranging from 20 to $120 \mu \mathrm{m}$ in diameters. In most of the pineal glands, these spherulites were loosely clustered in the parenchyma (Fig. B). In some tissues, however, a number of spherulites were conglomerated (Fig. A). These conglomerates sometimes showed amorphous structures as a result of several spherulites fused and combined together (Fig. C). The diameter of the largest exposed conglomerate was $1000 \mu \mathrm{m}$. The spherulites were often surrounded by a basket of

走查電子顕微鏡化よる牛の松果体脳砂の観察：河村統光・石橋武彦・宮本 元 (京都大学農学部 京都市 606) 

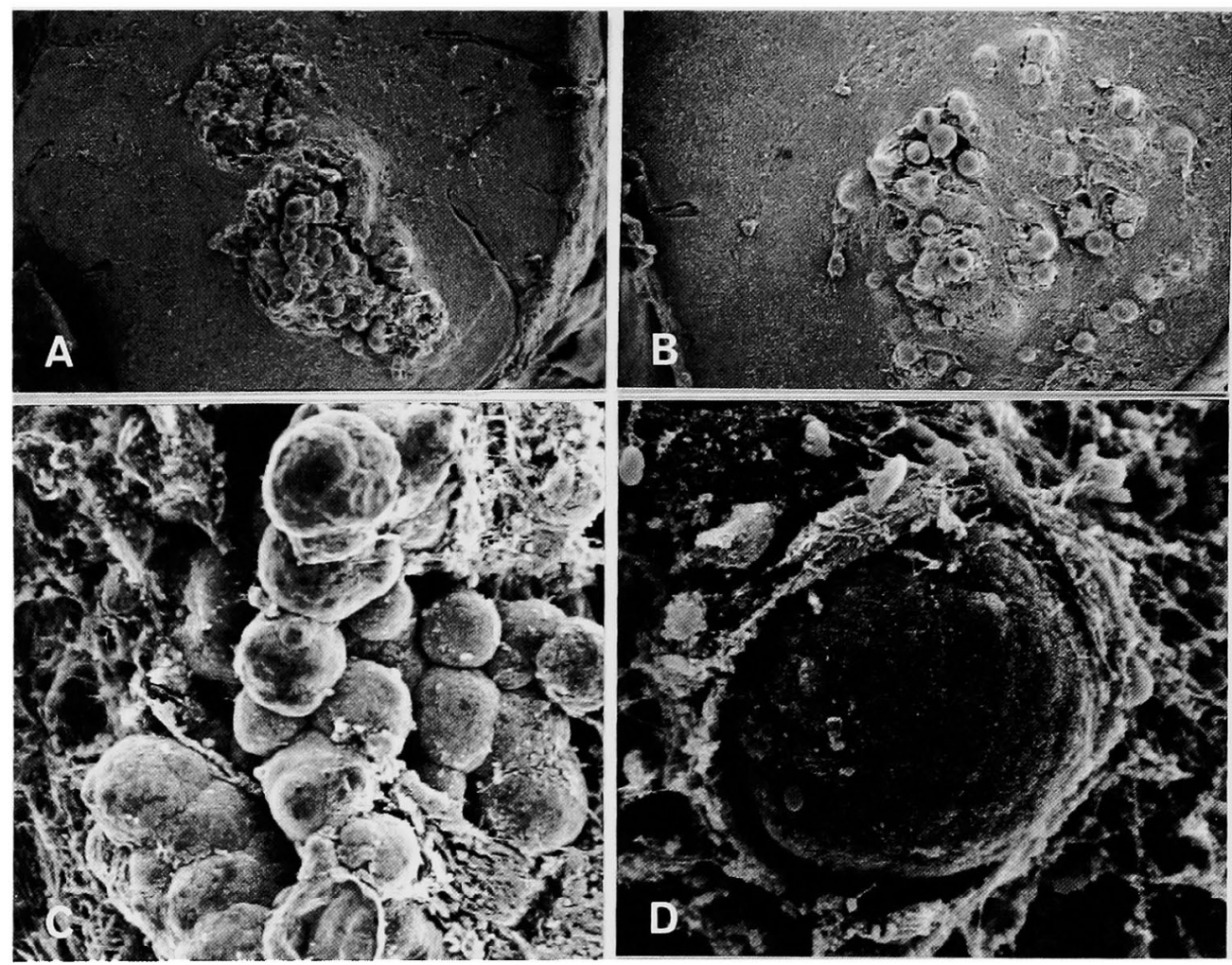

Explanation of Figures

Scanning electron micrographs of brain sand in the bovine pineal gland. (A) A photograph showing conglomerated concretions. Many of the spherulites make up the structure. $\times 20$. (B) A number of spherical concretions are loosely clustered in the central portion of the gland. $\times 20$. (C) Magnification of (A). An amorphous structure, which is the result of the fusion of several spherulites, is partly shown. $\times 140$. (D) A spherulite surrounded by a fibrillar basket. Its surface shows a mulberry-like structure. $\times 700$.

fibrous connective tissue (Fig. D).

The regional distribution of brain sand differs depending on the kind of animal. In the $\mathrm{rat}^{3)}$, the concretion were invariably present in the peripheral regions of the glands, while in the gerbil ${ }^{4)}$ and in humans ${ }^{5}$ ), these were found primarily in the central parenchyma as in cattle.

Concretions in the bovine pineal gland appeared either as loosely clustered spherulices or as a cluster of conglomerates fused with each other. These varied structures may indicate the morphological changes, of brain sand in their developing process : that is, primary formation of spherulites, their growth, reduction of the gaps between them, conglomeration and fusion. In the human being ${ }^{5,6)}$, most of the concretions were observed as mulberry-like structures. The conglomerate in the bovine pineal gland had a structure similar to that of the human. Since the human pineal glands observed by Kristic ${ }^{5)}$ and ALLEN et al. ${ }^{6)}$ were obtained from old individuals, it is natural. to say that these characteristics of the bovine pineal sand may also 
be those of well-developed brain sand.

Although it is well known that the presence of brain sand increases progressively with age ${ }^{1)}$, the origin and mechanism of its formation are poorly understood. Concerning the formation of concretions, LUKASZYK and REITER ${ }^{7)}$ proposed a hypothesis that polypeptides may be released from cells in conjunction with a carrier protein, and that the mechanism of secretion of the polypeptide into the vascular system may involve its exchange for calcium. DreHL ${ }^{3)}$ advanced another hypothesis that the concretions occurred by increasing the coagulation of intercellular organic debris mingled with minerals. This is due to a reduced drainage of tissue fluid in the pineal gland with age. From this study of the three-dimensional structure of the bovine pineal gland at SEM level, we cannot draw a conclusion on the origin nor on the formation mechanism of brain sand.

\section{Acknowledgement}

This study was supported in part by a grant from the Ministry of Education, Science and Culture, Japan.

\section{References}

1) Krause, W.J. and J.H. CutTs, Concise Text of Histology. Ist ed. 394-395. Williams and Wilkins. Baltimore. 1981.

2) Ishibashi, T., M. Mitsumoto and H. Miүamoto, Jpn. J. Zootech. Sci., 56 : 423-425. 1985.

3) DieHL, B. J.M., Cell Tiss. Res., $195: 359-366.1978$.

4) Reiter, R.J., M.G. Welsh and M.K. Vaughan, Am, J. Anat. $146: 427-432.1976$.

5) Kristić, R., Cell Tiss. Res., $174: 129-137.1976$.

6) Allen, D.J., J.S. Allen, L.J.A. Didio and J.A. McGrath, J. Submicrose. Cytol., $13: 675-695.1981$.

7) Lukaszyk, A. and R.J. Reiter, Am. J. Anat., 143:451-464. 1975. 